\title{
ANALYSIS OF CAUSATIVE FACTORS FOR STEM CANKER DISEASE EPIDEMIC ON RUBBER PLANTS IN SOUTH SUMATRA
}

\author{
Tri Rapani Febbiyanti ${ }^{1}$, Suryo Wiyono ${ }^{2}$, Sudirman Yahya $^{2}, \&$ Widodo $^{2}$ \\ ${ }^{1}$ Sembawa Research Center - Rubber Research Center, Indonesia \\ Jl. Raya Palembang-Betung Km.29 Palembang \\ ${ }^{2}$ Faculty of Agriculture, Bogor Agricultural Institute, Dramaga, Bogor, Indonesia \\ Jl. Kamper Kampus IPB Dramaga Bogor 16680 \\ E-mail: trifebbi@yahoo.com
}

\begin{abstract}
Analysis of causative factors for stem canker disease epidemic on rubber plants in South Sumatra. Lasiodiplodia theobromae is the cause of stem canker in the rubber plant (Hevea brasiliensis). Currently, data on environmental factors and cultivation techniques related to the development of stem canker are not available so research needs to be done on this subject. The objective of the study was to analyze environmental factors and cultivation techniques related to stem canker on rubber trees in southern Sumatra. Field observation was carried out at 21 locations in PT Perkebunan Nusantara VII and Experimental Garden of Sembawa Research Center, Indonesian Rubber Research Institute at Palembang to measure the severity and incidence of this disease. Besides that, the data of cultivation technique and the condition of the garden were taken from the officer at those locations. The location, clones, weed control and the number of plants/ha showed a correlation with the disease severity. There was a positive correlation between incidence and severity of the disease content of soil nitrogen, dust, clay and water as well as cation exchange capacity (CEC) were suggested to significantly contribute to the severity of stem canker.
\end{abstract}

Key words: Lasiodiplodia theobromae, principal component analysis, rubber, stem canker

\section{INTRODUCTION}

Rubber is a very strategic export commodity for the Indonesian economy. The area of rubber in Indonesia in 2013 reached 3,539,700 ha with $85 \%$ being smallholder rubber plantations. Furthermore, Indonesia's natural rubber production in 2012 was in the second position in the world after Thailand which reached 2.9 million tons, with a contribution to world rubber production reaching $27.06 \%$. The production generated foreign exchange for Indonesia of US \$ 4.8 million with export volume reaching 2.4 million tons (BPS, 2018).

The low production of smallholder rubber is caused by various factors, one of the which is disruption from various diseases (Basuki, 1982). The most important disease at this time in rubber plants especially in South Sumatra is stem canker caused by Lasiodiplodia theobromae. This disease can attack entres gardens, polybag plant material, immature plants and mature plants. Early symptoms of this disease are characterized by the formation of sporadic scabies which then fuse into broad lesions on the surface of the rubber stem. In the pith, the symptoms that appear are brown necrose that spreads to the canopy. Severe infections can cause bleeding in the latex, cracked skin, rotten area (Febbiyanti, 2017; Febbiyanti et al., 2019a; Febbiyanti et al., 2019b).

PT Perkebunan Nusantara VII reported that this disease had occurred in 2010 in the Padang Plawi Production Farm, Bengkulu, which attacked immature plants. Then, disease with similar symptoms also occurred in the Sembawa Research Institute Experimental Garden from 2011 until now. The results of the study by Pha et al. (2011) reported an epidemic with similar symptoms in traditional rubber plantations in Vietnam since 1921. Moreover, this stem disease became the first outbreak in 1998 in the area of traditional rubber plantations in Vietnam. This disease was reported to also attack rubber plantations in China, the Philippines, India, Bangladesh (Pha et al., 2011). In Indonesia, disease with similar symptoms was also found in almost all rubber plantation centers in southern Sumatra and attacked various types of rubber clones (Budiman \& Suryaningtyas, 2004).

This is a new disease and is growing very fast. The symptoms of stem canker seen in the field are not different from the results of the Postulate Koch test, and the pathogens isolated are also the same, which are 
the pathogens of this disease. Canker-causing pathogens are soilborne pathogens that can also be brought from grafting linkages (Febbiyanti, 2017).

Disease development is related to agroecosystems, so the linkage is needed to be found in the management of plantations. The agroecosystem is certainly related to the way of cultivation. The physical environment will simultaneously determine the development of pathogens and affect plant conditions so it will affect the attack of a type of disease. Therefore, it is necessary that information about rubber stem canker be extracted. The purpose of this study was to analyze causative factors of stem canker epidemic in rubber plants in Southern Sumatra and the assessment towards the incidence of the disease.

\section{MATERIALS AND METHODS}

Research Site. The research conducted included field observations, data collection on interviews and nutrient analysis. Field observations were carried out at the Sembawa Research Institute Experimental Site on BPM 24 rubber clone aged 3 and 8 years, RRIM 921 clone aged 5 years and IRR 112 clone aged 2 years with a spacing of $63 \mathrm{~m}$. Observations were also conducted at the production plantation of PT Perkebunan Nusantara VH Padang Plawi, Bengkulu (PB 260 clone aged 2 years, IRR 112 clone aged 3 and 2 years), Musilandas, Palembang (PB 260 clone aged 3 and 5 years) and Tulung Buyut, Lampung (PB 260 clone age 2 years) with a spacing of $73 \mathrm{~m}$.

Observations were carried out at 21 locations of experimental gardens. Observations included the severity and incidence of the disease, way of cultivaton, condition of the plantation, and soil samples in the root area of the sample tree.

Measurement of Disease Incidence (DI) and Disease Severity (DS). Observation of disease incidence and severity was carried out at the affected area from global observations. Each plantation received 200 plant samples observed at 5 observation points. One observation point was located in the middle of the plantation and two points were on each diagonal of the plantation. For each observation point, 40 plants were set close together to be observed. The disease incidence (DI) and disease severity (DS) values were calculated using the formula of Madden et al. (2007) as follows:

$$
\text { DI }=\frac{\text { number of infected plants }}{\text { number of observed plants }} \times 100 \%
$$

While for the DS

$$
\mathrm{DS}=\frac{\sum\left(\mathrm{n}_{\mathrm{i}} \times \mathrm{v}_{\mathrm{i}}\right)}{\mathrm{N} \times \mathrm{V}} \times 100 \%
$$

$\mathrm{DS}=$ disease severity

$\mathrm{n}_{\mathrm{i}}=$ number of sample plants with certain infection categories

$\mathrm{v}_{\mathrm{i}}=$ certain infection categories

$\mathrm{N}=$ number of plants observed

$\mathrm{V}=$ the highest infection category used

Category of disease severity: $0=$ branch skin tissue shows no symptoms of infection, $1=$ branch shows patches, scabies, bubbling rupture and black latex, 2 = scabies on peeling branches, drying out buds, bare leaves, broken branches, and visible symptoms of decay on the fracture marks, 3 = branch skins get peeled and rot, shoot canopy is still alive but there are many broken branches, fallen shoots, $4=$ broken canopy, dead plants (Situmorang, 2005). DI value was low if $\leq 10 \%$ and high if $\geq 10 \%$. DS value was low if $<20 \%$, moderate if 20 $40 \%$, and high if $>40 \%$. This classification was based on observers' experience in the field. If the condition is $\geq 10 \%$, the disease has reached the root, and the wooden vessels in the main stem have changed color.

\section{Epidemic Factors}

Cultivation Techniques and Plantations Conditions. Epidemic factors included cultivation techniques and soil fertility. Information on how to cultivate the plantations was obtained from the field assistant or foreman through interviews and direct observation. The cultivation techniques included: clones, plant age, production, fertilization and maintenance; the plantations conditions that need to be known included plant population, drainage and location of the plantations. The data obtained were arranged in the form of two-way contingency tables. Data on epidemic factors were arranged in rows and the disease severity was in columns. DI value was low if $\leq 10 \%$ and high if $\geq 10 \%$. DS value was low if $<20 \%$, moderate if $20-40 \%$, and high if $>40 \%$. This classification was based on observers' experience in the field. If the condition was in high severity, the disease would have reached the root and wood vessels in the main stem would have changed color.

Chemical and Physical Soil. Soil samples were taken from the field which showed high, moderate and low severity. Analysis of soil chemical and physical properties (N, P, K, Ca, Mg, Na, KB, CEC, pH, C-organic, soil texture) can be seen in Appendix 3. Data analysis was 
performed to determine each chemical and physical element that might be classified as important in its contribution to the disease severity. Rainfall and humidity data were also recorded daily, averaged, and summarized monthly. The data were correlated with disease incidence.

Data Analysis. Analysis of the correlation between DI and DS of stem canker appplied the regression. Then, an analysis was carried out to determine the possible correlation between cultivation and disease severity using the chi-square test. Chi-square test used in this case was chi-square test with freedom testing in the contingency table. The possible role of chemical and physical soil factors with disease severity was performed by multivariate analysis of the main components. Data processing software used in this study was SPSS version 24 and XLSTAT 2014.

\section{RESULTS AND DISCUSSION}

Observation results at 21 locations in several production plantations, such as Balit Sembawa experimental plantations, PTPN VII Tulung Buyut Lampung, Padang Plawi Bengkulu, and Musilandas Palembang, showed that the DS and DI were classified low to high, with a disease severity value of $12.89 \pm$ 7.69 and a disease incidence of $34.14 \pm 31.96$. The high DI value means that the disease in some locations has spread and is easily found. So even though the stem canker is still classified as a minor and new disease, based on this study, the attack has been widespread. This disease is easily found in almost every rubber plantation in southern Sumatra. The disease incidence is also higher because there is no control currently of this stem canker, so it is not impossible that one day it may lead to big problems.

Severe infections of stem canker cause bleeding in the latex, skin cracks, skin rot, and gumosis. In young plants, the initial infection in young shoots is small dark brown lesions that spread rapidly, skin rot, and infected leaves turning yellow due to lack of supply of nutrients and water. Severe infections led to death in the branches starting from the tip (shoot death) (Pha et al., 2011). Severe attacks resulted in dead rubber stands, which will reduce the number of plants per ha or increase the cost of patching (Pawirosoemardjo, 2004).

The regression results between DI and DS showed a real correlation between the two variables (Figure 1). Based on the calculation of the regression, DS can be used in assessing DS in stem canker that occurs in southern Sumatra, given the adjusted coefficient of determination ( $\mathrm{R}^{2} \mathrm{adj}$.) of $82.4 \%$. The DS value was positively correlated with the DS of 0.95 , and this was quite worthy to be used as a reference in assessing DS in the field. Determination of the regression equation used data from the calculation results of disease severity and incidence at each rubber plant age.

This result was very helpful for field staff who must provide an assessment in order to determine the yield loss relatively quickly. In addition, these results could also be used to establish policies in control. The disease severity was the closest basis in calculating yield loss. Severity values were not static and changed due to the influence of the physical environment, the phase of growing plants, and cultivation activities. But in annual plants such as rubber, fluctuations in disease severity

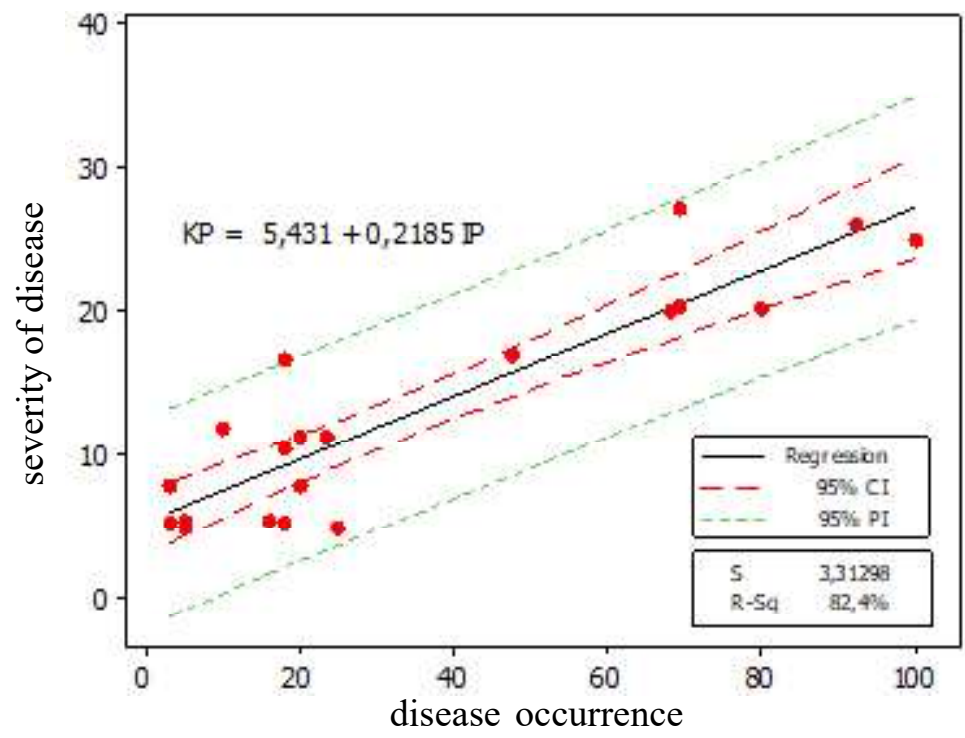

Figure 1. Relationship between disease incidence (DI) and disease severity (DS) on rubber stem canker 
and the environment around plants are relatively stable. The presence of pathogens and host plants are not much disturbed, unlike in seasonal plants.

Observations to determine DS values were very troublesome and time-consuming. DS value was determined by observing branches/twigs affected by canker stem cells. This observation wass sometimes difficult to do because of the relatively dense branch position, but by using the regression equation of the results of correlation between DI and DS, to know only about the the high rubber plants and are covered by the canopy of DI, the DS of stem canker has been countable.

Similar results show the relationship between the disease incidence and disease severity as in the case of soft rot in dragon fruit (Masyahit et al., 2009). Powdery mildew on strawberries also shows the same thing, that there is a correlation between the two indicators of attack (Carisse et al., 2013). In the case of powdery mildew on apples it can also establish a correlation between disease incidence and disease severity (Seem \& Gilpatrick, 1980), and the case banana leaf spot in Taiwan (Chuang \& Jeger, 1987).

\section{Cultivation Techniques and Plantations Conditions.}

Cultivation techniques and observed plantations conditions consisted of 16 variables: location, clones, weed control, age, plant population/ha, latex production/ year/ha, fertilization frequency/year, type of rootstock, girth, stem spacing, method fertilizer application, tapping system, fertilizer dose of $\mathrm{N}, \mathrm{P}, \mathrm{K}, \mathrm{Mg}$. This study showed a variable correlation between each variable with the severity of stem canker (Table 1).

Based on the results of the chi-square test of each of the cultivation technique variables and the condition of the plantations, it turns out that only the location, clones, weed control and plant populations showed a role in the severity of rubber stem canker disease (Table $1)$.

Clones. Table 1 shows that BPM 24 and PB 260 are clones that have high disease severity. This is caused by BPM 24 clone which has a naturally skin rupture character; this skin rupture is used by pathogens to enter the plant tissue and carry out the inoculation process. Furthermore, in addition to BPM 24 clone, mostly attacked clone is PB 260 clone. PB 260 is a clone that has been known to be susceptible to this stem canker. According to Kurnia (2005), in certain clone such as PB 260, the percentage of skin necrosis attacks can reach $20-50 \%$, which occurs after the panel move; PB clone is considered susceptible to skin necrosis, whereas RRIC 100, PR 261, PR 225 clones are considered to be quite tolerant of skin necrosis.

Location. Table 1 shows that the location of Sembawa has the highest disease severity compared to other locations. This is due to the fact that more clones planted at Sembawa are BPM 24 and PB 260 clones. The susceptible clone type is BPM 24, which causes Sembawa to have higher canker stem severity compared to other locations. The disease severity is also supported by rainfall and humidity at these locations (Figure 2).

Weed Control. High disease severity occurs in weed control by using herbicides compared to manual methods. The use of herbicides in controlling weeds can have an indirect impact on the development of stem canker. In general, the consequences arising from the intensive use of herbicides make plants weak, so that existing diseases can be more developed. The use of glyphosate herbicides in plants that are resistant or not to herbicides has an impact on decreasing number of dentrification microbes and other microbial communities in the rhizosphere (Hart et al., 2009). In addition, the use of herbicides is able to increase plant susceptibility caused by (a) reducing defense structures in plant tissues, (b) stimulating the release of host plant exudates, (c) stimulating growth of pathogens, (d) suppressing the ability of microflora competition with potential pathogens. The use of glyphosate herbicides on a large scale can have direct impacts, such as inducing attenuation in plant defenses and increasing population and pathogen virulence (Altman \& Campbell, 1977). Moreover, indirect effects such as inhibiting plant growth and vigor due to accumulation of glyphosate in the root system, shoots and reproductive tissue, affect the availability of nutrients needed in the physiological process related to plant resilience (Johal \& Huber, 2009) and the reduced phytoalexin which results in weaker plant resistance (Duke et al., 2007). Herbicide residues interfere with the growth of horticultural crops and food and some types of weeds (Carpenter \& Boutin, 2010). Glyphosate herbicides also reduce the availability of nutrients by reducing their solubility for nutrient absorption. Glyphosate also stimulates soil pathogens to attack the roots, stems, and canopy of plants (Huber, 2010). The use of glyphosate also has an impact on reducing the number of dentrification microbes and other microbial communities in the rhizosphere (Hart et al., 2009). 
Table 1. The relationship between cultivation techniques and garden conditions to disease severity

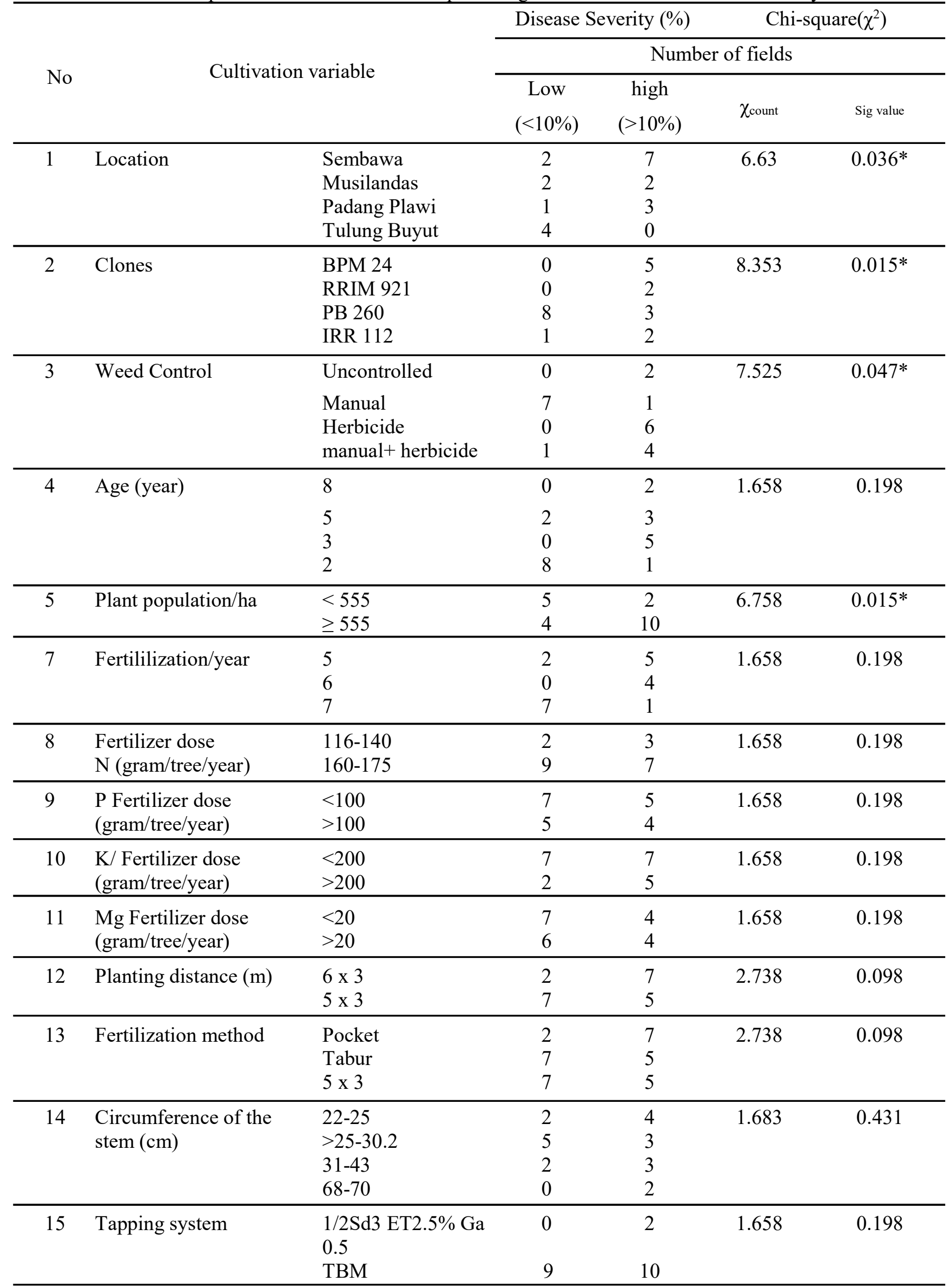




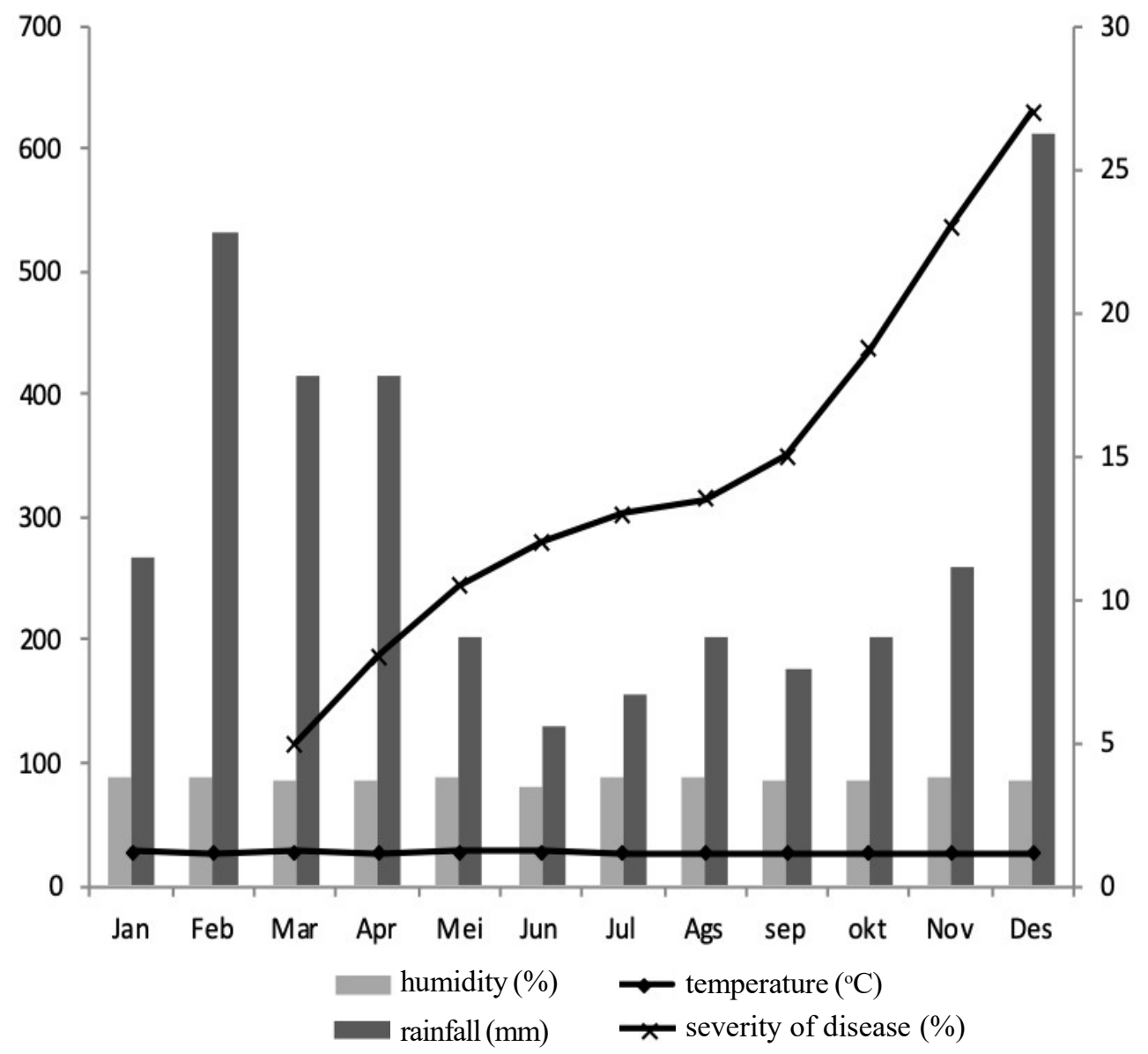

Figure 2. The development of rubber stem cancer in Sembawa in relation to weather factors measured in 20132014

Plant Population. Based on Table 1, the higher plant population/ha was $\geq 555$ which had a higher disease severity compared to the lower plant population, which was $<555 /$ ha. The emergence of disease epidemic was determined by 3 causative factors that take place in the same period, such as the presence of susceptible plants, virulent pathogens, and environmental/climate factors that are very suitable for the development of the disease (Butler \& Jadhay, 1991). Microclimate, such as temperature, humidity, rainfall, wind, and radiation affect each level of the pathogen development cycle and plant diseases. Humidity, either as a relative humidity or free water on plant surfaces, plays a very important role in the epidemic of plant diseases. Humidity of air around trees is influenced by rainfall, wind, irradiation and also temperature. In plant populations $\geq 555 /$ ha the severity of stem canker is higher, this is related to the humidity around the plantations. The rubber plant has a wide canopy. This canopy affects humidity, free water on the plant's surface and the temperature below it, and the amount of light entering under the canopy. Humidity plays a role in the release of pathogenic conidia from the picnidia and splashing water helps in the process of spreading the conidia. L. theobromae can form structures that survive under adverse environmental conditions for development. Under favorable environmental conditions, where humidity, nutrition and temperature are high, pathogens will germinate immediately and then penetrate into plant tissue. Different environmental temperature conditions are very high between day and night, especially during the dry season, which is an environment that facilitates the development of this pathogen (Figure 2). Weak plant conditions supported by high humidity will support the penetration of the new host plant tissue. Penetration will then be followed by colonization, where pathogens will grow and develop in the host plant tissue. The critical phases of the pathogen are just before penetration occurs. In this phase the control will be more effective than if it has been advanced (Henuk, 2010).

Chemical and Physical Soil. The severity of the disease can be affected by growth conditions. The physical and chemical nature of the soil determines plant 
growth, and this can also have an impact on the severity of the disease. In grapes the diversity of yields and fruit quality is influenced by the physical and chemical soil and plant conditions, especially those related to $\mathrm{N}, \mathrm{Ca}$, $\mathrm{Mg}, \mathrm{Fe}, \mathrm{S}, \mathrm{Zn}, \mathrm{Mn}$ and $\mathrm{B}$. Accurate interpretation between soil properties and fruit quality applied multivariate statistical analysis approach (Arno et al., 2012).

The disease incidence and severity are related to cultivars and production systems. Types of cultivars and production systems will be related to plant growth patterns so that they will form microclimates that can inhibit or support disease development (Carisse et al., 2013). In addition, the emergence of a disease epidemic is determined by 3 factors that take place in the same period, namely the presence of susceptible plants, virulent pathogens, and environmental/climate factors that are very suitable for the development of the disease. (Butler \& Jadhav, 1991).

In the results of the analysis of the main components of the physical chemistry of the soil against the disease severity, it turned out that only the chemical properties of the soil such as CEC and $\mathrm{N}$ determined the severity of stem canker (Table 2). The physical properties of the soil which was significantly influenced the disease severity were percentage of dust, clay, and water content. Physical and chemical variables of the soil that played a role in determining the disease severity were indicated by number above 0.75 . The greatest role was shown by the $\mathrm{N}$ element. This can be determined based on the values in the commonly used score coefficients similar to the regression coefficients. The greater the score coefficient, the greater the impact of changes in the variable value on the increase or inhibition of weathered stem disease. The increase in $\mathrm{N}$ elements in the soil causes the severity of the disease to decrease, and vice versa.

Certain nutrient conditions individually did not directly influence the development of disease. The effect will be seen if it is combined with other nutrients as a whole, thereby increasing plant resistance. The application of $\mathrm{P}$ fertilizer alone can suppress attacks, but when combined with $\mathrm{N}$, attacks will be lower. Fertilization does not reduce the ability of pathogen sporulation but causes plants to become more resistant (Okori et al., 2004) that can reduce new infections.

The element $\mathrm{N}$ influences vegetative growth. The $\mathrm{N}$ element plays a role in stimulating growth, the formation of chlorophyll and amino acids (Tisdale et al., 1975). N plays an important role as a constituent of chlorophyll, so the leaves will look green (Mangel \&
Kirby, 1987). Pawirosoemardjo (1984) stated that the element $\mathrm{N}$ is the constituent of phytoalexin. In rubber leaves that are attacked by Colletotrichum gloesporioides, phytoalexin can be toxic to pathogens or act as a phenolic compound that can limit damage caused by pathogen, through a process called hypersensitivity.

Based on the results of principal componen analysis (AKU/PCA), it is seen that the higher the $\mathrm{N}$ content, the lower the disease severity. This was related to the form of nitrogen taken by plants. Nitrogen is taken up by plants in form of $\mathrm{NH}_{4}^{+}$and $\mathrm{NO}_{3}^{-}$, in soils which contain a lot of clay, nitrogen in $\mathrm{NH}^{+}$will be difficult to use by plants, because $\mathrm{N}$ in the form of $\mathrm{NH}_{4}^{+}$is bound by clay mineral species of mica hydrate (illit). This is supported by the results of the analysis of soil physical properties showing \% clay and \% dust significantly related to disease severity. Besides $\mathrm{NH}_{4}^{+}$which cannot be utilized by plants, $\mathrm{N}$ in the form of $\mathrm{NO}_{3}^{-}$(nitrate) is easily washed away by rain water (leaching). The condition of land that has a lot of rain/water streak will have a low N. This is also supported by the results of the analysis of soil physical properties which showed $\%$ water content correlating with disease severity. $\mathrm{N}$ is a mobile element, easily leached and volatile, so the plants oftenly became deficiency (Brady \& Weil, 2002). Plants are not able to take nitrogen in form of $\mathrm{NH}_{4}^{+}$and $\mathrm{NO}_{3}{ }^{-}$ because the physical and chemical properties of this soil result in disturbed plant growth and weak plants. $L$. theobromae is a weak pathogen that may infect unhealty plant. A weak plant condition makes it easy for $L$. theobromae to infect.

Based on AKU/PCA results, it is also seen that the CEC value was significantly related to the disease severity. This is because the CEC was related to soil fertility and clay content in the soil. Soil with high CEC when dominated by base cations, $\mathrm{Ca}, \mathrm{Mg}, \mathrm{K}, \mathrm{Na}$ (high base saturation) can increase soil fertility, but if dominated by acid cations, Al, H (low base saturation), it can reduce soil fertility. The results of the soil analysis carried out showed that the $\mathrm{pH}$ of the soil was classified as acid $(\mathrm{pH} \leq 5.5)$. This condition will affect the availability of nutrients that can be taken by plants. Acidic soil conditions cause reduced availability of $\mathrm{P}$ and deficiency of the $\mathrm{Ca}, \mathrm{K}, \mathrm{N}, \mathrm{Mg}$, Mo, S element. Nutrient status is in a not-available status, and the low application of fertilizer causes inhibited growth and increases the susceptibility of plants to infection by pathogens. The acidity of soils classified as very acidic, such as Al, Fe and Mn, is becoming more available, and this can poison the roots. Damage to the root cells will 
Table 2. Value of variable components of soil fertility and constituent factors and standard score coefficients for the severity of rubber stem canker, result of AKU/PCA

\begin{tabular}{lcccc}
\hline \multirow{2}{*}{ Variable } & \multicolumn{3}{c}{ Component } \\
\cline { 2 - 5 } & Factor 1 & Factor 2 & Factor 3 & Coefficient Raw Score $\left.^{*}\right)$ \\
\hline N-total $(\%)$ & 0.8035 & 0.2365 & 0.0933 & -0.2696 \\
$\mathrm{P}(\mathrm{ppm})$ & 0.4352 & -0.3258 & -0.3079 & -0.0723 \\
$\mathrm{~K}(\mathrm{cmol} / \mathrm{kg})$ & 0.1590 & 0.0802 & 0.4889 & 0.7652 \\
$\mathrm{Al}^{3+}$ & -0.2179 & 0.3916 & 0.1857 & 0.2641 \\
$\mathrm{Ca}(\mathrm{cmol} / \mathrm{kg})$ & 0.4343 & -0.6567 & -0.4089 & -0.0469 \\
$\mathrm{Mg}(\mathrm{cmol} / \mathrm{kg})$ & 0.2982 & -0.4872 & 0.5101 & 0.4456 \\
$\mathrm{KTK}(\mathrm{cmol} / \mathrm{kg})$ & 0.9187 & 0.0527 & 0.1005 & 0.0712 \\
$\mathrm{~KB}(\%)$ & -0.5345 & -0.6180 & -0.1280 & 0.2450 \\
$\mathrm{pH}\left(\mathrm{H}_{2} \mathrm{O}\right)$ & 0.3095 & -0.5849 & 0.1687 & -0.1464 \\
$\mathrm{C}-$ organic $(\%)$ & 0.5345 & 0.6192 & 0.0430 & -0.3802 \\
Sand $(\%)$ & -0.5122 & -0.6085 & 0.0370 & -0.3509 \\
Dust $(\%)$ & -0.0939 & 0.7745 & -0.2895 & 0.2609 \\
Clay $(\%)$ & 0.8200 & -0.2541 & 0.3515 & 0.1109 \\
Water moisture $(\%)$ & 0.9020 & -0.1156 & 0.0822 & 0.0273 \\
\hline
\end{tabular}

The bolded numbers for each column show a strong correlation between the factors formed and the soil fertility variable.

*) Listed one of the three standardized score coefficients for AKU results

occur so that the plant becomes weak. If this condition lasts for a long time it will certainly interfere with plant growth, increasing the chance of disease pathogens.

Common base cations are the nutrients needed by plants. Base saturation is closely related to soil $\mathrm{pH}$, where soils with low $\mathrm{pH}$ generally have low base saturation. Soil with low base saturation means the sorption complex is filled more by acid cations, which are $\mathrm{Al}^{+++}$and $\mathrm{H}^{+}$. If the amount of acid cation is too much, especially $\mathrm{Al}^{+++}$, it can be toxic to plants. This situation is found in acid soils (Ige et al., 2005). Generally, soil reactions only have an effect on soil-borne diseases. An example of the effect of soil acidity on diseases caused by pathogens is the effect of $\mathrm{pH}$ on scurvy (Streptomyces scabies) on potato tubers. If the $\mathrm{pH}$ is reduced to 5.4-5.2, very few tubers have scabies. Thus, this disease is controlled by applying sulfur to the soil as much as $300-500 \mathrm{~kg} / \mathrm{ha}$ (Hao et al., 2008).

$\mathrm{CEC}$ is also associated with clay content in the soil. Based on AKU/PCA results, it appears that the clay percentage is higher, so the disease severity is also higher. This is related to the ability to hold water on the ground. Soil containing high clay will have the higher ability to hold water (from the AKU/PCA results, water content had a positive correlation with disease severity). According to Yew (1991), soil with a clay texture has the capacity to retain water and nutrients better than soil with a sand texture.
The high groundwater content is also supported by the results of AKU/PCA regarding the percentage of water content in the soil, which had a positive effect on the disease severity. High soil moisture affects the development of plant pathogens, especially soil borne pathogens such as $L$. theobramae, moist soil conditions become a good place to grow and survive for soil borne pathogens.

\section{CONCLUSION}

There was a linear and positive relationship between disease incidence and severity with a correlation of 0.95 . This relationship can be used as a reference in providing an assessment of the disease severity in the field and also determining loss of results. Chi-square test of cultivation techniques and field conditions on the disease severity showed that clones, location, weed control and population density/ha was significantly related to the development of stem canker in the field. BPM type 24 clone was that one prone to stem canker, and moist and inundated areas were the ones that accelerated the spread of pathogenic inoculums. Some soil chemical properties such as CEC and $\mathrm{N}$ affect the severity of rubber stem canker. In addition to chemical properties, physical properties of the soil also determine disease severity, namely the level of dust content, clay level, and moisture content. The 
increase in $\mathrm{N}$ elements in the soil caused the disease severity to decrease, and vice versa. CEC value was significantly related to disease severity. This is because CEC was related to soil fertility and also clay content in the soil. Soil with clay texture had a better capacity to hold water and nutrients than soil with sand texture.

For further research, it is necessary to study the correlation between cultivation variables, the disease severity, and the incidence of rubber stem canker in several locations in smallholder rubber plantations. It is important to know the epidemic of rubber stem canker more broadly.

\section{ACKNOWLEDGMENT}

The research thanks to head officer of Sembawa Research Center, Indonesia Rubber Research Institute for providing research facilities and also very grateful to Dr. Karyudi and Dr. Thomas for useful comments on this manuscript.

\section{REFERENCES}

Altman J \& Campbell CL. 1977. Effect of herbicide on plant diseases. Annu Rev. Phytopathol. 15: 361385.

Arno J, Rosell JR, Blanco R, Ramos MC, \& MartinezCasasnovas JA. 2012. Spatial variability in grape yield and quality influenced by soil and crop nutrition characteristics. Precis. Agric. 13(3): 393-410.

Basuki. 1982. Penyakit dan Gangguan pada Tanaman Karet. Pusat Penelitian dan Pengembangan Perkebunan, Tanjung Morawa.

Badan Pusat Statistik. 2018. Statistik Karet Indonesia 2018. Katalog 5504002, Jakarta.

Budiman A \& Suryaningytas H. 2004. Status penyakit lapuk cabang batang Fusarium pada tanaman karet Hevea di daearah sentra Sumatera Bagian Selatan dan Kalimantan Selatan. In : Aron S, Arief B, Heru S, Thomas, Mudji L, \& Anang G (Eds.). Prosiding Pertemuan Teknis "Strategi Pengelolaan Penyakit Tanaman Karet untuk Mempertahankan Potensi Produksi Mendukung Industri Perkaretan Indonesia Tahun 2020. pp. 119-133. Balai Penelitian Sembawa, Palembang.

Butler DR \& Jadhav DR. 1991. Requirement of leaf wetness and temperature for infection of groundnut by rust. Plant Pathol. 40(3):395-400.
Carisse O, Lefebvre A, der Heyden HV, Roberge L, \& Brodeur L. 2013. Analysis of insidence-severity relationships for strawberry powdery mildew as influenced of cultivar, cultivar type, and production systems. Plant Dis. 97(3): 354-362.

Carpenter D \& Boutin C. 2010. Sublethal effects of the herbicide glufosinate ammonium on crops and wild plants: short-term effects compared to vegetative recovery and plant reproduction. Ecotoxicology. 19(7): 1322-1336.

Chuang TY \& Jeger MJ. 1987. Relationship between incidence and severity of banana leaf spot in Taiwan. Phytopathology. 77:1537-1541.

Duke SO, Rimando AM, Pace PF, Reddy KN, \& Smeda RJ. 2007. Isoflavone, glyphosate, and aminomethyl phosphonic acid levels in seeds of glyphosatetreated, glyphosate-resistant soybean. J. Agric Food Chem. 51(1): 340-344.

Febbiyanti TR. 2017. Diagnosis dan Status Penyakit Kanker Batang Tanaman Karet di Sumatera Selatan. Dissertation. Institut Pertanian Bogor, Bogor.

Febbiyanti TR, Wiyono S, Yahya S, \& Widodo. 2019a. Lasiodiplodia theobromae fungus causing stem cancer disease on rubber tree (Hevea brasiliensis) in Indonesia. J. Agron. 18(1): 4128

Febbiyanti TR, Widodo, Wiyono S, \& Yahya S. 2019b. Pengaruh $\mathrm{pH}$ dan waktu penyimpanan terhadap pertumbuhan Lasiodiplodia theobromae penyebab kanker batang tanaman karet. Indonesian J. Nat. Rubb. Res. 37(1): 1-10.

Hart MM, Powell JF, Gulden RH, Dunfield KE, Pauls KP, Swanton CJ, Klironomos J, Antunes PM, Koch AM, \& Trevors JT. 2009. Separating the effect of crop from herbicide on soil microbial communities in glyphosate-resistant corn. Pedobiologia. 52(4): 253-262.

Hao X, Godlinski F, \& Chang C. 2008. Distribution of phosphorus forms in soil following long term continuous and discontinuous cattle manure applications. Soil Sci. Soc. Am. J. 72(1): 90-97.

Henuk JBD. 2010. Identifikasi dan Uji Patogenisitas Penyebab Busuk Pangkal Batang pada Jeruk (Citrus spp.) dari Beberapa Sentra Produksi Jeruk di Indonesia. Tesis. Institut Pertanian Bogor, Bogor. 
Huber. 2010. What's new in chemicaland crop nutrient interactions current update. In: Dale F (Ed.). Proceedings Fluid Fertilizer Forum, Scottsdale. Leikam. Indianapolis Marriot East Hotel. Indiana.

Ige DV, Akinremi OO, \& Flaten DN. 2005. Direct and indirect effects of soil properties on phosphorus retention capacity. Soil Sci. Soc. Am. J. 71(1): 95-100.

Johal GS \& Huber DM. 2009. Glyphosate effects on diseases of plants. Eurp. J. Agron. 31(3): 144152.

Kurnia D. 2005. Kinerja berbagai klon karet pada pertanaman komersial PT. Socfin Indonesia. In: Daslin A, Istianto, Sumarmadji, Kustyanti, Suhendry I, \& Siagian N (Eds.). Prosiding Lokakarya Nasional Pemuliaan Tanaman Karet 2005. Balai Penelitian Sungai Putih. Pusat Penelitian Karet. Medan, Sumatera Utara.

Madden LV, Hughes G, \& Bosch FVD. 2007. The Study of Plant Disease Epidemics. APS Press, Minnesota.

Mangel K \& Kirby EA. 1987. Principles of Plant Nutrition. Institute Worblaufen-Bern, International Potash, Switzerland.

Masyahit M, Sijam K, AwangY, \& Satar MGM. 2009. First report on bacterial soft rot disease on dragon fruit (Hylocereus spp.) caused by Enterobacter cloaceae in Peninsular Malaysia. Int. J. Agric. Biol. 11(6): 659-666.

Okori P, Rubaihayo PR, Adipala E, \& Dixelius C. 2004. Interactive effects of host, pathogen and mineral nutrition on grey leaf spot epidemics in Uganda. Eur. J. Plant Pathol. 110(2): 119-128.

Pawirosoemardjo S.1984. Beberapa Aspek Hubungan Patogen Inang dalam Penyakit Gugur daun Colletotrichum pada Karet. Disertasi. Universitas Gadjah Mada, Yogyakarta.
Pawirosoemardjo S. 2004. Manajemen pengendalian penyakit penting dalam upaya mengamankan target produksi karet nasional tahun 2020. In: Aron S, Arief B, Heru S, Thomas, Mudji L, \& Anang G (Eds.). Prosiding dalam Pertemuan Teknis Strategi Pengelolaan Penyakit Tanaman Karet untuk Mempertahankan Potensi Produksi Mendukung Industri Perkaretan Indonesia Tahun 2020. pp 21-45. Balai Penelitian Sembawa, Pusat Penelitian Karet, Palembang.

Pha TA, Dung PT, Hieu ND, Mai NN, \& Nghia NA. 2011. Disease caused by Botryodiplodia theobromae Pat. on rubber tree in Vietnam: current status and recent studies. IRRDB International Rubber Conference. Chiang Mai.

Seem RC \& Gilpatrick JD. 1980. Incidence and severity relationships of secondary infections of powdery mildew on apple. Phytopathology. 70: 851-854.

Situmorang A. 2005. Diktat Pelatihan untuk Peneliti Puslit Karet. Balai Penelitian Sembawa, Pusat Penelitian Karet. Palembang.

Tisdale SL, Nelson WL, \& Beaton JD. 1975. Soil Fertility and Fertilizers. MacMillan Publishing Co. Inc., New York.

Weil RR \& Brady NC. 2002. The Nature and Properties of Soils. Upper Saddle River, New Jersey.

Yew FK. 1991. Soil factors affecting rubber performance. Planters' Bull. 1991(2): 47-51. 